DOI: 10.17707/AgricultForest.65.4.04

\author{
Fidèle MULUMEODERHWA ${ }^{1,2^{*}}$, Aristide MANIRIHO ${ }^{1,3}$, \\ Dimas MANIRAKIZA', Germaine FURAHA ${ }^{2}$, \\ Jean Luc MASTAKI ${ }^{2,4}$, Philippe LEBAILLY ${ }^{1}$
}

\title{
RISK ANALYSIS IN THE PEASANT FRAMEWORK: EMPIRICAL ANALYSIS OF FARMERS IN SOUTH KIVU, DEMOCRATIC REPUBLIC OF CONGO
}

\begin{abstract}
SUMMARY
This study attempted to highlight the risks threatening the peasant farmers and affecting the development of their activities in the locality of Mbinga Sud in Kalehe Territory and the localities of Bugorhe and Irhambi in Kabare Territory in South Kivu, Eastern Democratic Republic of Congo. Data were collected using a questionnaire from a sample of 150 peasant farmers randomly selected and fairly distributed in the three locations of the study area. Descriptive statistics were used in data analysis. The results showed that financial risks were not among the significant threats to farm development in the short term. Nevertheless, farm operations were more exposed to risks in Mbinga Sud Locality than in Irhambi and Bugorhe Localities with respect to financial autonomy, access to short-term liquidity and availability of investment funds. The results also revealed that natural hazards (including flooding and erosion) were not currently among the threats of farming activities. For the whole study area, the respondents confirmed that the risks of flooding and erosion are weak, at the rates of $73.3 \%$ and $78 \%$ respectively.

On the other hand, low prices of agricultural commodities, climatic disturbances, crop diseases, crop theft and raptors were the major long-term farm threats in the study area as confirmed by $60.0 \%, 47.3 \%, 40.7 \%, 23.3 \%$ and $45.3 \%$ of the respondents, respectively. From these findings, we recommend that the strategies for sustainable environment management should be initiated; the proximity of extension services to farmers should be enhanced; and security should be permanently kept and guaranteed.

Keywords: Risks, peasant framework, farm activities, South Kivu, Democratic Republic of Congo.

\footnotetext{
${ }^{1}$ Unity of Economics and Rural Development, Gembloux Agro-Bio Tech, University of Liège, Gembloux, BELGIUM; ${ }^{2}$ Faculty of Economics and Management Sciences, Evangelical University of Africa, Bukavu, Democratic Republic of CONGO; ${ }^{3}$ School of Economics, University of Rwanda, Kigali, RWANDA; ${ }^{4}$ Trade and Markets Division (EST), FAO, Rome, ITALY *Corresponding author: fidmude@yahoo.fr

Paper presented at the $10^{\text {th }}$ International Scientific Agricultural Symposium "AGROSYM 2019".

Notes: The authors declare that they have no conflicts of interest. Authorship Form signed online.
} 


\section{INTRODUCTION}

Nearly $80 \%$ of the world's extremely poor people live in rural areas and rely heavily on agriculture for their survival (Farouque \& Takeya, 2007). Stimulating the productivity of agricultural activities can be one of the most effective ways to combat poverty as the food system provides more jobs than any other sector in many countries (Banque mondiale, 2017; Laplante, 2014; Ferraton and Touzard, 2009). According to Chausse et al. (2012), rural income growth not only reduced rural poverty, but also urban poverty when the opposite was not true. Peasants are farm households, with access to a piece of land and utilizing mainly household labor in farm production. They are located in a larger dominant economic and political system that could affect their production behavior, but fundamentally they are characterized by partial engagement in markets, which are often imperfect or incomplete (Ellis, 1992).

A big number of people farming very little land under pressing natural conditions trapped their families in a life of poverty and what has been described as "agricultural involution"; that is, increasing intensity of labor use merely to maintain an unstable subsistence (Forrest-Zangh and Donaldson, 2010). The economic importance of peasants has been highlighted by the dimensions of the food crises of the 1970s and by the recognition that they are often cheap food suppliers and a source of cheap labor for agriculture and industrial development (Deere and de Janvry, 1979).

For most developing countries, the agricultural sector is considered a key sector for their economies and one of the solutions to improving the living conditions of more of the poor people who depend on them (Rutten and Boto, 2014; Imboden, 2014; Miller and Jones, 2013; Yumkella et al, 2012). Although many African economies depend on a few raw materials or semi-processed commodities, agricultural products account for a large share of their total export earnings (AfDB, 2017) and contribute to GDP growth. According to the 2008 World Bank report on agriculture for development (World Bank, 2008), GDP growth due to agriculture is at least twice as effective in poverty reduction as GDP growth in other sectors.

Family farming has many advantages: it is an effective lever for combating poverty and undernourishment and participates extensively in the enhancement and protection of natural resources and landscapes (Ferraton and Touzard, 2009; Laplante, 2014), and produces more than $70 \%$ of the world's food, provides food security for hundreds of millions of family farmers and millions of others, and is the largest employer of the family assets that make up the bulk of this workforce (Ministry of Agriculture-French Republic, 2013). Besides, small peasant farmers are facing a lower opportunity cost of labor than big commercial farms (Barrett, 1996).

Despite a range of solutions that they can provide, family farms face a variety of challenges, such as limited access to resources, lack of succession and poor or absent training (McGlynn et al, 2013), lack of appropriate markets (FAO, 2015), the threats that climate change poses to their livelihoods (FAO, 2016), the 
difficulty of accessing credit because their financial performance is low and risky (Prévitali, 2015), etc. Beyond the constraints related to production and outlets, family farmers also face with wider difficulties, including poor health conditions, lack of social protection, low level of education, lack of infrastructure and public facilities (Laplante, 2014).

The agricultural sector of the Democratic Republic of Congo (DRC) is experiencing several problems such as the degradation of production and transport infrastructure, the dependence on imports of cheap food products, the low technical level, the lack of quality inputs (seeds, fertilizers, tools, ...), the lack of agricultural credit, the failure of the agricultural extension system, the priority given to the mining sector, etc. (Lebailly et al, 2015). The province of South Kivu, while having agricultural potential that would allow it to be selfsufficient in food and to be a net exporter, is characterized by a significant proportion of a rural population, mostly poor, poverty driven by a very high unemployment rate, a very worrying nutritional situation (Mastaki, 2006), food dependence on neighboring provinces and countries (Vwima et al, 2013), a virtual absence of financial institutions in rural areas, financial services of microfinance institutions (MFIs) and savings and credit cooperatives (SACCOs) geared towards income-generating activities requiring short-cycle financing (trade, etc.), lack of diversity of financial products for agriculture (such as agricultural insurance, commercial credit, etc.), lack of adequate rural infrastructure (agricultural feeder roads, conservation infrastructure, markets, distribution networks for agricultural products, etc.), adverse business climate for investors, the problem of information asymmetry in the agricultural sector which benefits intermediaries, the rural exodus that is of great concern especially among young people, the low profitability of agricultural activities and its very risky nature which does not encourage financial institutions to lend to farmers, etc.

It is worth to note that risk plays an important role in peasant agriculture. "Different choices by farmers do not depend on differences in their attitudes towards risk, but on the differences in their subsistence needs, resource endowments and perceptions of the riskiness among competing activities. Empirical models of decision-making under risk require knowledge of the risk preferences of decision-makers" (Shahabuddin, Mestelman, \& Feeny, 1986).

Many studies, such as those by Lidsky et al (2017), Cordier et al (2008) and Couty (1989), have been conducted by analyzing agricultural risks in a dispersed manner with a greater focus on their management. In this study, we focus our attention on a diversity of risks threatening agricultural holdings in the territories of Kalehe and Kabare; two areas located in the east of the Democratic Republic of Congo, where populations have experienced dramatic situations of persistent insecurity and political instability. Thus, we have grouped risks into five categories, including financial risks, natural risks, occupational risks, price risks (Cordier et al, 2008) and other risks (crop theft, crop destruction by animals, insecurity) less present in risk analysis research. The seminal work of Chayanov 
in the 1920s emphasized the influence of family size and structure on peasant economic behavior, through the subjective evaluation of labor within the household, in the absence of the labor market (Chayanov, 1966).

There have been drastic developments in the agrarian farming systems that affected significantly the rural transformation (Zangh and Donaldson, 2010), but the situation in the Democratic Republic of Congo seems to be the worst in the world. In the light of the whole issues of family farming here above discussed, solutions deserve to be found to enable the agricultural sector of South Kivu Province to answer certain essential questions of sustainable development.

\section{MATERIAL AND METHODS}

The data used are from the farmers'survey carried out in May -August 2018. The questionnaire used to collect data focused on socioeconomic characteristics of the farmer respondents and mainly on the main risks associated with the faming activities. A random sample of 150 peasant farmers randomly selected and distributed equitably in the localities of Bugorhe, Irhambi in Kabre territory and the locality of Mbinga-Sud in Kalehe territory were interviewed. To this end, the sampling technique by reasoned choice was used based on the selection criteria, including the market orientation of all or part of the production and the diversification of agricultural activities.

We used the farmers' experiences for risk analysis. A three-point Likert scale (High=3, Medium=2, and Low=1) was used to test the extent at which the farmers were facing different risks. Descriptive statistics (frequencies, percentages, and means) were used in the data analysis. The $\mathrm{z}$ test was performed under the software of Statistical Package for Social Sciences (SPSS) to show the differences or not in the proportions between the columns (localities); the result of the $\mathrm{z}$ test being represented by the letters $\mathrm{a} / \mathrm{b}$ in index in the results tables.

\section{RESULTS AND DISCUSSION}

The table 1 describes the characteristics of the respondents. Men represent $70 \%$ of the farmers surveyed, while women represent only $30 \%$. The most farmers (84.7\%) were aged between 20 and 59 years, with an average age of 48 years. The majority of farmers attended secondary school $(44.1 \%)$, others attended primary (39.6\%) and university (6.7\%), while the illiterate respondents represented $8.7 \%$.

The results from the analysis of the level at which the peasant farmers were facing different risks are summarized in Table 2. The agricultural risks were categorized as financial risks (indebtedness, low access to investment funds, high interest rate, low level of financial autonomy, problem of illiquidity in short run), natural risks (climate change, plant diseases, floods, erosion, plant devastators), price risks (price fluctuations, low prices/non-remunerating prices), professional risks (occupational diseases, exposure to the harms of pesticides, occupational accidents), and miscellaneous risks (crops theft, crops destruction, insecurity). 
Table 1. Characteristics of the respondents.

\begin{tabular}{|l|l|c|c|}
\hline Characteristics & Attribute & Frequency & Percentage \\
\hline \multirow{3}{*}{ Sex } & Male & 105 & 70.0 \\
\cline { 2 - 4 } & Female & 45 & 30.0 \\
\hline \multirow{4}{*}{ Education } & $20-59$ & 127 & 84.7 \\
\cline { 2 - 4 } & More than 59 & 23 & 15.3 \\
\cline { 2 - 4 } & No education & 13 & 8.7 \\
\cline { 2 - 4 } & Primary & 59 & 39.3 \\
\cline { 2 - 4 } & Secondary & 66 & 44.1 \\
\cline { 2 - 4 } & University & 10 & 6.7 \\
\cline { 2 - 4 } & Other & 2 & 1.3 \\
\hline
\end{tabular}

* The mean age of the respondents was 48 years.

The results showed that the financial risks for these farmers do not pose a significant threat to the development of their farms in the short term.Debt risk and high interest rate were not part of harmful risks given that the majority of farmers $(80.7 \%$ and $73.3 \%$ respectively) reported they were less exposed to them,. This could be due to the lack of financial institutions specializing in granting agricultural loans; the existing institutions are more demanding and charge high interest rate, and consequently, fewer farmers have access to credit. This supports Olagunju and Adeyemo's (2007) report that the cost for access to loan is among the big problems of farmers and the finding by Lallau et al. (2018) who stated that donors have failed to integrate sustainable financing into their development assistance programs.

This also contrasts Prévitali's (2015) idea who showed that farm indebtedness is one of the factors in the modernization of agriculture, because it can make it possible to enlarge the cultivated land. Consequently, the modernization of agriculture in these areas will continue to face difficulties if access to finance does not improve through the restructuring of the financial sector in the Democratic Republic of the Congo. Other problems are the lack or low level of financial autonomy, lack or low access to short-term liquidity and the issue of availability of investment funds. These are among the significant risks facing the peasant farmers as reported by more than $35 \%, 38 \%$, and $21.3 \%$, respectively. The Mbinga Sud area in Kalehe Territory is more exposed than the other two areas in Kabare Territory. This situation is crucial and cannot enable the agriculture to be a sustainable source of livelihood for the farmers in the study area, as Prévitali (2015) pointed out that such financial problems do not make the farming profession peaceful. At the 0.05 threshold, the result of the ztest (letters a and $b$ in index) shows that there is a significant difference in the proportions between the locality of Mbinga-Sud and the localities of Bugorhe and Irhambi with regard to financial autonomy, access to short-term liquidity and the availability of capital. If better measures are not taken, these farms are likely to be vulnerable in the medium and long term. 


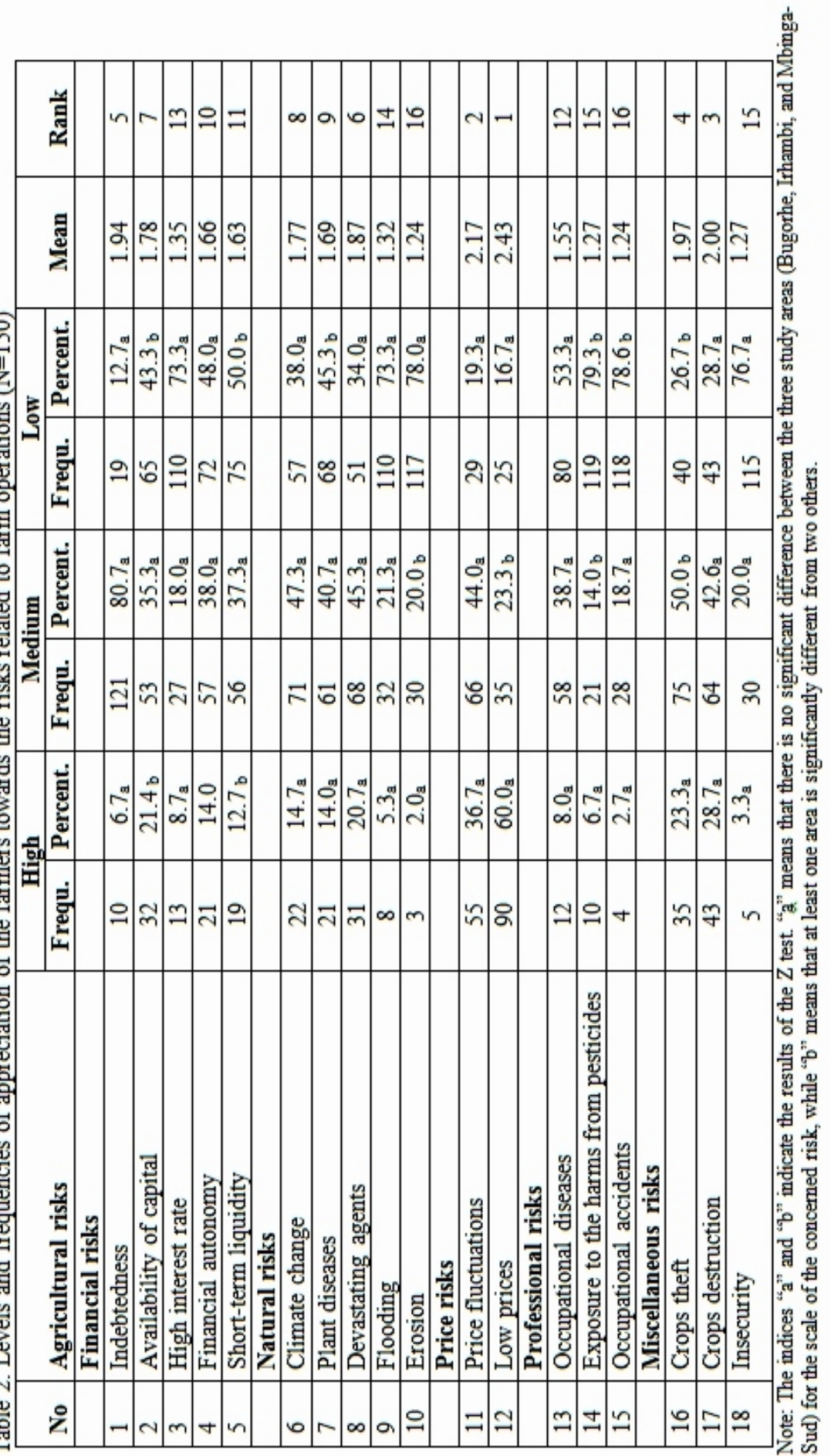


Flooding and erosion are not currently a threat to $73.3 \%$ and $78 \%$ respectively of farms in the three communities, although the average erosion risk in Mbinga South (14.7\%) is higher than in the other communities included in the study (test $\mathrm{z}$, represented by letters $\mathrm{a}$ and $\mathrm{b}$ in index). This is because there are several fields in the locality of Mbinga-Sud that are located on hills compared to the localities of Bugorghe and Irhambi. On the other hand, climatic disturbances, crop diseases and grazing livestock are threats to farms, considering their average and high level of appreciation. At the 0.05 threshold, the results of the z-test show that there is no significant difference in the proportions between the three localities with regard to climatic disturbances and raptors, whereas there are differences between the locality of Bugorhe and the other two localities with regard to the risk of crop diseases. Cochereau (1989) had already mentioned the impact of insect pests on crop loss by proposing alternative solutions to address them. But the specificity for these farmers in these localities is that they are simultaneously confronted with the problem of climate change, crop diseases and grazing livestock; the first problem having an influence on the latter two. Unfortunately, we have noticed the absence of the State in solving these problems. For example, farmers do not have access to weather forecast information (Ngomba Yashele and Nsombo Mosombo, 2017) to enable them to plan their activities (Eldin, 1989). Farmers reported that in 2018 their production decreased due to rainfall disruptions and the presence of caterpillars that attacked maize, especially in Irhambi and Bugorhe. One Bugorhe farmer reported: "I produced 1.15 tonnes of maize in season B in 2018, while for season 2017 A, I produced 4.75 tons with the same factors of production".

The volatility of agricultural commodity prices is a major threat to farms. For $60 \%$ of farmers, this risk is high, while it is estimated at an average level for more than $23 \%$ of farmers. Cordier et al (2008) described price volatility risk as a systemic risk because it can affect several agents at the same time, and it is a predominant risk in agriculture. It is the imposition of selling prices by buyers that is most annoying to farmers in these three communities; a factor that has a significant influence on price stability. Lidsky et al (2017) add that climate change also increases price volatility because of its unpredictable effects on crop yields. Price regulation would therefore be a possible solution to mitigate the effects of this risk in these communities. Although there is no significant difference between the proportions of high risk (36.7\%) and medium risk (44\%) in relation to the risk associated with fluctuations in input prices, it is important to note that this risk is a strong long-term threat to farms.

Overall, there are not too many occupational risks associated with the job of farmer in the three localities, except what occupational diseases (average risk $38.7 \%$ ) resulting from bad weather (rain, cold, heat) and heavy skilled work intense risks or physical constraints by Arnaudo et al. (2013). "A disease is recognized as professional if it is a direct consequence of a worker's exposure to a physical, chemical, or biological hazard" (Lienard et al, 1998). The lack of some protective equipment (boots, gloves, etc.) exposes farmers to bites by 
snakes and other insects, but also to injuries due to improper handling of agricultural tools. At 0.05 the result of the z-test shows that the exposure to plant protection products is lower in the locality of Mbinga-South, as there are few farmers who practice crops requiring the prices of these products. This is not the case for farmers in developed countries who are more exposed to chemicals. In France, for example, $42.8 \%$ of farmers are exposed to at least one chemical (Arnaudo et al, 2013) because of the intensification and modernization of their agriculture. Studies on health problems associated with exposure to phytosanitary products (Jas, 2010) should be conducted in Irhambi and Bugorhe to define strategies for controlling this risk.

Farmers regard the destruction and theft of crops as a risk and a constraint for the development of their farms. For 50\% of the farmers, crop theft, although considered of average level, poses a threat to their farms. It should be noted that $23.3 \%$ of the operators stated that this risk is high. Theft is much more frequent in Mbinga-Sud and Irhambi than in the locality of Bugorhe. For some farmers, unemployment is one of the causes of crop theft; for others, theft is favored by the presence of gunmen in some villages. Nearly $29 \%$ of farmers believe crop destruction is a high risk for their farms, while for nearly $43 \%$ of farmers this is a medium risk. Theft and destruction of crops therefore pose a threat to farms in these three study areas, regardless of their level of risk.

In summary, the results show that the five most important risks of peasant farmers in the study area are the low prices, the price fluctuations, the crops destruction, the crop theft; while five least important ones are occupational accidents, erosion, insecurity, exposure to the harms of pesticides, and flooding.

\section{CONCLUSIONS}

Farmers in South Kivu, and in particular those in Kalehe territory and Kabare, are working in an uncertain and unstable environment. This is explained by the problem of access to financial and institutional services, such as access to agricultural credit due to the lack of specialized financial institutions, the absence of agricultural insurance companies, the problem of access to information about weather forecasts, the lack of basic infrastructure (market, agricultural service road, storage facilities for products), etc. Faced with this situation, farms in these two territories are exposed to innumerable risks that threaten their development.

According to survey results, financial risks are not significant threats to agricultural development in the short term. Nevertheless, farms were more at risk in the locality of South Mbinga than in the localities of Irhambi and Bugorhe with regard to financial self-sufficiency, access to short-term liquidity and the availability of investment funds. Floods and erosion are not currently a threat to $73.3 \%$ and $78 \%$ of farms in these areas. On the other hand, climatic disturbances (47.3\%), crop diseases (40.7\%) and devastating agents (45.3\%) are major longterm risks facing peasant farmers in the study area. The low price of agricultural commodities is a major threat to $60 \%$ of farms. Price regulation would be a possible solution to mitigate the effects of this risk. There are not too many 
occupational risks associated with farming in these three areas. In addition, climatic disturbances, crop and plant diseases, crop rustling and crop pests were the main long-term agricultural threats in the study area, as confirmed by $47.3 \%$, $40.7 \%, 23.3 \%$ and $45.3 \%$ of respondents, respectively. On the basis of these results, we recommend that sustainable environmental management strategies be initiated, that the proximity of agricultural extension services be strengthened and that security is maintained and guaranteed on an ongoing basis.

\section{REFERENCES}

Arnaudo, B., Léonard, M., Sandret, N., Cavet, M., Coutrot, T., Rivalin, R., \& Thiérus, L. (2013). Les risques professionnels en 2010: de fortes différences d'exposition selon les secteurs (Professional risks in 2010: large differences in exposure by sectors). Références en Santé au Travail, volume(133), 5974.

Banque Mondiale. (2017). Mettre fin à l'extrême pauvreté. Promouvoir une prospérité partagée (Eradicating extreme poverty for the promotion of shared prosperity). Washington, D.C.: Banque mondiale.

Barrett, C. B. (1996). On price risk and the inverse farm size-productivity relationship. Journal of Development Economics, 51(2), 193-215.

Chausse, J.-P., Kembola, T., \& Ngonde, R. (2012). Chapitre 1. L'agriculture: pierre angulaire de l'économie de la RDC (Agriculture at the centre of the economy of the Democratic Republic of Congo). J. Herderschee, D. Mukoko Samba \& M. Tshimenga Tshibangu (Eds.), Résilience d’un Géant Africain: Accélérer la Croissance et Promouvoir l’Emploi en République Démocratique du Congo, 2, 197.

Chayanov, A. V. (1966). The Theory of Peasant Economy. Homewood, IL: Richard Irwin.

Cochereau, P. (1989). L'insecte et le risque agricole. In A travers champs. Le risque en agriculture (M. Eldin, P. Milleville, p. 624). Paris: ORSTOM.

Cordier, J., Erhel, A., Pindard, A., \& Courleux, F. (2008). La gestion des risques en agriculture de la théorie à la mise en oeuvre: éléments de réflexion pour l'action publique (Risk management in agriculture: from theory to application, basis of public action). Notes et Etudes Economiques, volume(30), 32-71.

Couty, P. (1989). Risque agricole, périls économiques (Farming risks, sources of economic perils). In Eldin, M., \& Milleville, P. (Eds.) A travers champs. Le risque en agriculture (pp. 561-568). Paris: ORSTOM.

Deere, C. D., \& de Janvry, A. (1979). A Conceptual Framework for the Empirical Analysis of Peasants. American Journal of Agricultural Economics, 61(4), 601611.

Eldin, M. (1989). Analyse et prise en compte des risques climatiques pour la production végétale (Analysis and consideration of climatic risks for crop production). In Eldin, M., \& Milleville, P. (Eds.). Le Risque en Agriculture. Dynamique des systèmes agraires (47-63). Paris: ORSTOM.

Ellis, F. (1992). Agricultural policies in developing countries. Cambridge: Cambridge University Press.

FAO (2016). La situation mondiale de l'alimentation et de l'agriculture: changement climatique, agriculture et sécurité alimentaire (The State of Food and Agriculture: Climate Change, Agriculture and Food Security). Rome: Organisation des Nations Unies pour l'Alimentation et l'Agriculture (FAO). 
FAO. (2015). La situation mondiale de l'alimentation et de l'agriculture 2015. Protection sociale et agriculture: briser le cercle vicieux de la pauvreté rurale (The State of Food and Agriculture 2015. Social Protection and Agriculture: Breaking the Vicious Circle of Rural Poverty). Rome: FAO.

Farouque, G., \& Takeya, H. (2007). Farmers' perceptions of integrated soil fertility and nutrient management for sustainable crop production: a study of rural areas in Bangladesh. Journal of Agricultural Education, 48(3), 111-122.

Ferraton, N., \& Touzard, I. (2009). Comprendre l'agriculture familiale (Understanding the family farming). Versailles, Wageningen, Gembloux : Quae, CTA, Presses agronomiques de Gembloux.

Forrest Zhang, Q., \& Donaldson, J. A. (2010). From peasants to farmers: Peasant differentiation, labor regimes, and land-rights institutions in China's agrarian transition. Politics \& Society, 38(4), 458-489.

Imboden, K. (2014). Coordination des politiques de finance agricole en Afrique Enseignements tirés du Burkina Faso, de l'Ethiopie, du Ghana, du Maroc et de la Zambie (Coordination of Agricultural Finance Policies in Africa - Lessons from Burkina Faso, Ethiopia, Ghana, Morocco and Zambia). Abidjan: Banque africaine de développement.

Lallau, B., Laissus-Benoist, P., \& Mbetid-Bessane, E. (2018). Introduction : la résilience peut-elle passer de la théorie aux pratiques? (Introduction: Can resilience go from theory to practice?). Revue internationale des études du développement, 235(3), 925.

Laplante, M. (2014). L'agriculture familiale. Avis du Conseil économique, social et environnemental (Family farming. Opinion of the Economic, Social and Environmental Council). Journal Officiel de la République Française, 2014-26, 174.

Lebailly, P., Michel, B., M’Vubu, N., \& Roger, A. (2015). Quel développement agricole pour la RDC? (What agricultural development for the DRC?). Conjonctures congolaises 2014: politiques, territoires et ressources naturelles: changements et continuités, 45-64.

Lidsky, V., Maudet, C., Malpel, G.-P., Gerster, F., Helfter, M., Lejeune, H., \& LeTheule, F.-G. (2017). Les outils de gestion des risques en agriculture (Risk management tolls in agriculture). Paris: Inspection générales des finances et Conseil général de l'alimentation, de l'agriculture et des espaces ruraux, République Française.

Lienard, M., Treppoz, H., Delemotte, B., Adjemian, A., Mercat, F. X., \& Choutet, P. (1998). Infections transmises par les tiques et maladies professionnelles en agriculture (Infections transmitted by ticks from insects and occupational diseases in agriculture). Médecine et Maladies Infectieuses, 28(4), 367372.

Mastaki, N. J. L. (2006). Le rôle des goulots d`étranglement de la commercialisation dans laadoption des innovations agricoles chez les producteurs vivriers du Sud-Kivu, Est de la R.D.Congo (The role of market bottlenecks in the adoption of agricultural innovations among food producers in South Kivu, Eastern part of Democratic Republic of Congo). Gembloux : Faculté Universitaire des Sciences Agronomiques de Gembloux.

McGlynn, D., Buchholzer, F., Cooper, V., Gardner, S., Hudson, T., O’Hara, E., Zona, A. (2013). L'agriculture familiale (Family farming). Revue rurale de l’UE, (17), 140.

Miller, C., \& Jones, L. (2013). Financement des chaînes de valeur agricoles - Outils et leçons (Financing agricultural value chains: tools and lessons). Rome: Organisation des Nations Unies pour l'Alimentation et l'Agriculture (FAO). 
Ngomba Yashele, K., \& Nsombo Mosombo, B. (2017). Perception paysanne des impacts de la variabilité climatique autour de la station de l’INERA/Kipopo dans la province du Katanga en République Démocratique Congo (Farmer perception of the impacts of climate variability around the INERA / Kipopo station in the Katanga province of the Democratic Republic of Congo). VertigO (La revue électronique en science de l'environnement), 17(3), 1-15.

Olagunju, F. I., \& Adeyemo, R. (2007). Determinants of repayment decision among small holder farmers in Southwestern Nigeria. Pakistan Journal of Social Sciences, 4(5), 677-686.

Prévitali, C. (2015). Les conditions du suicide des professionnels agricoles (The conditions of suicide among agricultural professionals). Pensée plurielle, 38(1), 105-121.

RDC, Ministère de l'agriculture et du Développement Rural. (2013). Plan national d'investissement agricole (PNIA) 2014 - 2020 (National Agricultural Investment Plan 2014-2020). Kinshasa: République Démocratique du Congo.

RDC, Ministère de l'Agriculture et du Développement Rural. (2014). Rapport du 10 ème cycle d'analyse du Cadre Intégré de Classification de la Sécurité Alimentaire (Report on the 10th cycle of the analysis of the Integrated Framework of Classification of Food Security). Kinshasa: Ministère de l'Agriculture et du Développement Rural.

RDC, Ministère de l'Agriculture, Pèche et Elevage. (2009). Note de politique agricole (Note of agricultural policy). Kinshasa : République Démocratique du Congo.

RDC/Ministère de l'Agriculture et du Développement Rural. (2012). Programme National d’Investissement Agricole (National Agricultural Investment Plan). Kinshasa: République Démocratique du Congo.

RDC/Province du Sud-Kivu. (2006). Document de Stratégie de la Croissance et de la Réduction de la Pauvreté (Economic Growth and Poverty reduction Strategy Paper). Bukavu, Sud-Kivu.

Rutten, L., \& Boto, I. (2014). Révolutionner le financement des chaînes de valeur agricoles (Revolutionizing the financing of agricultural value chains). Bruxelles: CTA.

Shahabuddin, Q., Mestelman, S., \& Feeny, D. (1986). Peasant behaviour towards risk and socio-economic and structural characteristics of farm households in Bangladesh. Oxford Economic Papers, 38(1), 122-130.

Vwima, S., Mastaki, J.-L., \& Lebailly, P. (2013). Le rôle du commerce frontalier des produits alimentaires avec le Rwanda dans l’approvisionnement des ménages de la ville de Bukavu, province du Sud-Kivu (The role of cross border trade in food products with Rwanda in the household supply of the city of Bukavu, South Kivu Province, Democratic Republic of Congo). In Mobilités internationales, déséquilibres et développement: vers un développement durable et une mondialisation décarbonée ? Orléans: Université d'Orléans.

World Bank (2008). World development report 2008: Agriculture for development. Washington: World Bank.

Yumkella, K. K., Kormawa, P. M., Roepstorff, T. M., \& Hawkins, A. M. (2012). Agribusiness pour la prospérité de l'Afrique (Agribusiness for the prosperity of Africa). Vienne: Organisation des Nations Unies pour le Développement Industriel. 